\title{
NOTES
}

\section{IN THE WAKE OF CATALONA: AN ALTERNATIVE MODEL TO SAFEGUARD RESEARCH PARTICIPANTS' INTERESTS IN THEIR BIOLOGICAL MATERIALS}

\author{
Kaitlin M. Piccolo ${ }^{\dagger}$
}

\section{INTRODUCTION}

On February 23, 2006, four men were indicted in connection with a $\$ 4.6$ million dollar body-snatching scheme. ${ }^{1}$ While working for Biomedical Tissue Services Limited, the men allegedly paid funeral homes $\$ 1,000$ per body from which they mined tissues, organs, and bones without the consent of the deceased's families. ${ }^{2}$ They then sold the parts for research, medical education, and transplantation. ${ }^{3}$ Once harvested for valuable parts, the corpses were either cremated or stuffed with "PVC plumbing pipe in place of the bones" and sewed back up for a funeral. ${ }^{4}$

Although an exceptionally gruesome analogy, the Biomedical Tissue Services scandal somewhat parallels how "elite universities ... [and] prominent pharmaceutical companies" $"$ have abused the rights of living persons with respect to their human biological materials. Such abuse has

* J.D., The University of Pittsburgh School of Law, 2008; B.S., The Pennsylvania State University, 2005. Special thanks to my parents, my sister, and Jeffrey N. Rosenthal.

1. Lori Andrews, The Battle Over the Body, Trial, Oct. 2006, at 22.

2. Id.

3. Id.

4. $I d$.

5. Id. 
prompted exploration for a new legal framework to govern human biological materials. One proposed framework would grant people a property interest in their biological materials. ${ }^{6}$

"The ramifications of recognizing and enforcing a property interest in body tissues are not known, but are greatly feared . ..." Historically, both courts and legislatures have resisted acknowledging property rights in the human body and its constituent parts. ${ }^{8}$ Since Colonial America, the common law governed the disposition of human corpses. Not until the twentieth century did American courts grant the deceased's next of kin a quasi-property right in the deceased's body. ${ }^{9}$ These rights include: "the right to possession and custody of the body for burial, the right to have it remain in its final resting place, and the right to recover damages for any outrage, indignity, or injury to the body." 10

During the mid-twentieth century, as biomedical technology advancements created demand for transplantable tissue, the Uniform Anatomical Gift Act (UAGA) was drafted and adopted throughout the United States. ${ }^{11}$ The Act authorizes competent adults to gift all or any part of their bodies upon death for medical research, education, or transplantation. ${ }^{12}$ However, it fails to address both inter vivos donations and sales of all or any part of the body. ${ }^{13}$

6. See generally Michelle Oberman, When the Truth is Not Enough: Tissue Donation, Altruism, and the Market, 55 DePAul L. Rev. 903, 907 (2006) (arguing that families should be compensated for providing access to human tissue of deceased family members); Richard Gold, Owning Our Bodies: An Examination of Property Law and Biotechnology, 32 SAN DIEGO L. REv. 1167, 1170 (1995) (discussing whether property law should govern distribution of and control over human biological materials); William Boulier, Note, Sperm, Spleens, and Other Valuables: The Need to Recognize Property Rights in Human Body Parts, 23 Hofstra L. Rev. 693, 696 (1995) (recommending that courts place body parts under property law).

7. Moore v. Regents of the Univ. of Cal., 793 P.2d 479, 498 (Cal. 1990) (Arabian, J., concurring) (citations omitted).

8. Boulier, supra note 6, at 694-95.

9. U.S. Congress, Office of Tech. Assessment, New Developments in Biotechnology: Ownership of Human Tissues and Cells 72 (1987), available at http:/govinfo.library.unt.edu/ ota/Ota_3/DATA/1987/8719.PDF [hereinafter OwNERShip OF Human Tissues AND CELls RePORT].

10. Id. Courts actually first granted the next of kin an enforceable right to possession of a body for burial during the nineteenth century. $I d$. The law governing human corpses began nearly 1,000 years ago in English ecclesiastical courts, which had "complete jurisdiction over all matters concerning burials and disposition of corpses." Id. Only in the nineteenth century was this dominion challenged by "the growth of medical schools and their need for cadavers." Id.

11. Id. at 75 .

12. Unif. Anatomical Gift Act §5(a), 8A U.L.A. 53 (amended 2006). Donations can be made by will, by a gift document (such as a donor card), or through the deceased's next of kin. Id. $\S \S 5(\mathrm{~b}), 9$.

13. OWnership of Human Tissues and Cells Report, supra note 9, at 75. Inter vivos donations 
In 1984, Congress established the National Organ Transplant Act (NOTA),${ }^{14}$ the current version of which prohibits the sale of "the human (including fetal) kidney, liver, heart, lung, pancreas, bone marrow, cornea, eye, bone, and skin or any subpart thereof and any other human organ . . . specified by the Secretary of Health and Human Services by regulation." 15 "The social policy behind this law is 'ethical and humane,' and designed so that scientific research would not be pursued $\mathrm{a}[\mathrm{t}]$ the physical cost of the economically and socially deprived." $" 16$ However, the law does not apply to human tissue and cell sales for non-transplantation purposes, such as research. ${ }^{17}$

As illustrated above, "the law is often slow to come to grips with technology, especially when technology advances so quickly."18 Currently, research participants lack property rights in their excised biological materials. ${ }^{19}$ Accordingly, this Note explores whether any context exists in which research participants should retain limited property rights in such materials. Part I examines the current legal framework governing the rights of research participants, with special attention to informed consent and property laws. Part II then explores important policy considerations implicated in discerning whether research participants should retain limited property rights. Next, Part III recommends that a property law concept, traditionally used in the real property donation context, be used to secure research participants appropriate rights based on significant policy considerations. Finally, Part IV briefly summarizes the points addressed in this Note.

are donations made during the donor's lifetime. Id.

14. Pub. L. No. 98-507, 98 Stat. 2339 (1984) (codified as amended at 42 U.S.C. $\S \S 273-274 \mathrm{~g}$ (2000)).

15. 42 U.S.C. $\S 274 \mathrm{e}(\mathrm{c})(1)(2000)$.

16. Judith B. Prowda, Moore v. The Regents of the University of California: An Ethical Debate on Informed Consent and Property Rights in a Patient's Cells, 77 J. Pat. \& Trademark OfF. Soc'y 611, 625 (1995) (citation omitted); see also World Medical Association, Declaration of Helsinki: Ethical Principles for Medical Research Involving Human Subjects, If A-8, at 2 (2000) (recognizing vulnerability of "economically and medically disadvantaged" and their need for special protection) [hereinafter DeClaration of Helsinki].

17. Ownership of Human Tissues and Cells Report, supra note 9, at 76.

18. Boulier, supra note 6, at 695 .

19. Prowda, supra note 16, at 629; see also infra Part I. 


\section{Legal Framework}

Three landmark cases govern research participants' rights with respect to their human biological materials. This section explores all three cases in terms of both informed consent and property laws. The first case, Moore $v$. Regents of the University of California ${ }^{20}$ established that a clinical patient lacks property rights in biological materials excised during the patient's diagnosis or treatment. ${ }^{21}$ Following Moore, Greenberg v. Miami Children's Hospital Research Institute, Inc., ${ }^{22}$ held that a research volunteer lacks property rights in biological materials donated to medical research. ${ }^{23}$ Most recently, Washington University v. Catalona ${ }^{24}$ determined that both clinical patients and research volunteers ${ }^{25}$ who donate biological materials for medical research do not retain ownership rights allowing them to direct the use and transfer of the materials. ${ }^{26}$

\section{A. Moore v. Regents of the University of California}

In Moore, after the plaintiff, John Moore, was diagnosed with hairy cell leukemia, ${ }^{27}$ he went to the UCLA Medical Center for a second opinion. ${ }^{28}$ Once there, Dr. David Golde performed extensive tests on Moore during which he extracted Moore's biological materials. ${ }^{29}$ As a result, Dr. Golde both confirmed Moore's diagnosis and discovered that his biological materials were extremely valuable. ${ }^{30}$ In fact, Dr. Golde knew access to such materials would provide him with great "competitive, commercial, and scientific advantages." ${ }^{11}$

\section{793 P.2d 479 (Cal. 1990).}

21. Id. at 493 .

22. 264 F. Supp. $2 d 1064$ (S.D. Fla. 2003).

23. Id. at 1074 .

24. 437 F. Supp. 2d 985 (E.D. Mo. 2006).

25. For purposes of this Note, clinical patients and research volunteers are collectively referred to as "research participants."

26. Catalona, 437 F. Supp. $2 \mathrm{~d}$ at 1002.

27. Hairy cell leukemia is a rare cancer of the blood and bone marrow in which the bone marrow produces excessive lymphocytes (a type of white blood cell) which may cause the spleen to swell. U.S. National Institutes of Health, National Cancer Institute, General Information About Hairy Cell Leukemia, http://www.cancer.gov/cancertopics/pdq/treatment/hairy-cell-leukemia (last visited Sept. 5, 2008). The disease is called "hairy cell leukemia" because the cells look "hairy" when viewed under a microscope. Id.

28. Moore v. Regents of the Univ. of Cal., 793 P.2d 479, 481 (Cal. 1990).

29. Id. For these tests Dr. Golde withdrew blood and bone marrow from Moore. Id.

30. $I d$.

31. $I d$. 
Once finished with the tests, Dr. Golde recommended Moore have his spleen removed..$^{32}$ After Moore consented to the removal, Dr. Golde arranged to conduct purely scientific research on Moore's spleen following the operation. ${ }^{33}$ This research was unrelated to Moore's care. ${ }^{34}$ Dr. Golde, however, did not inform Moore of his intentions. ${ }^{35}$

Upon Dr. Golde's instruction, Moore returned to the UCLA Medical Center several times for post-operative care, during which Dr. Golde withdrew additional biological materials from Moore. ${ }^{36}$ Again, without Moore's consent, Dr. Golde conducted purely scientific research on Moore's biological materials unrelated to his care. ${ }^{37}$ From Moore's biological materials, Dr. Golde eventually created a cell line on which the Regents obtained a patent worth an estimated $\$ 3.01$ billion dollars. ${ }^{38}$ Once Moore discovered the patent, he brought suit for lack of informed consent ${ }^{39}$ and conversion. ${ }^{40}$

\section{Lack of Informed Consent}

The California Supreme Court first determined that Moore had a cause of action for lack of informed consent. ${ }^{41}$ Specifically, the court held "a physician who is seeking a patient's consent for a medical procedure must, in order to satisfy his fiduciary duty and to obtain the patient's informed consent, disclose personal interests unrelated to the patient's health, whether research or economic, that may affect his medical judgment." ${ }^{42}$

\section{Conversion}

The court, however, held that Moore lacked a cause of action for conversion because he did not retain an ownership interest in his excised

\footnotetext{
32. Id.

33. $I d$.

34. $I d$.

35. Id.

36. Id. Dr. Golde informed Moore that such visits were essential to his health. Id. The biological materials withdrawn on these later visits included blood, skin, bone marrow, and sperm. Id.

37. Id.

38. Id. at 482

39. The court used "lack of informed consent" and "breach of fiduciary duty" interchangeably. Id. at 485 .

40. Id. at 482 n. 4

41. Id. at 485 .

42. Id. (footnote omitted).
} 
biological materials. ${ }^{43}$ The court gave three reasons for its holding. First, no court to date had granted a patient an ownership interest in such materials. ${ }^{44}$ Second, California state law heavily regulated the disposition of human biological materials, drastically limiting a patient's interest in them. ${ }^{45}$ Lastly, because the patented cell line was "both factually and legally distinct" from Moore's biological materials, he lacked a property interest in the cell line and its derivative products. ${ }^{46}$

Next, the court declined to extend conversion law to cover the use of human biological materials in medical research for three reasons. ${ }^{47}$ First, a balancing of the prevailing policy considerations counseled against extension. ${ }^{48}$ Second, the legislature was the better forum to decide whether to extend conversion liability. ${ }^{49}$ And lastly, the court lacked a pressing need to extend conversion law because of the lack of an informed consent remedy. ${ }^{50}$

43. Id. at 489 .

44. Id.

45. Id. For example, California law regulated the "procurement, processing, and distribution of human blood." Id. at 489 n.23 (citing CAL. Health \& SAFETy Code $§ 1601$ (West 1990) (repealed 1991)). Also, state law dictated that a dead human fetus of less than twenty weeks uterogestation be disposed of by either burial or incineration. Id. at 489 n.24 (citing CAL. HeALTH \& SAFETY CODE $§ 7054.3$ (West 2007)). In addition, state law allowed the coroner to remove corneal eye tissue from a body for scientific, transplant, or therapeutic purposes under certain circumstances. Id. at 489 n.26 (citing CAL. GOv'T CODE $\$ 27491.47$ (West 2007)).

46. Id. at 492 .

47. Id. at 493 .

48. Id. Specifically, patient rights to autonomy and privacy were adequately protected by physician disclosure obligations such that the court need not risk chilling scientific investment, research, and development with the threat of conversion liability. Id. at 494.

49. Id. at 493 .

50. Id. In his dissent, Justice Mosk illustrated three major flaws in the majority's analysis. First, the issue of whether a patient retains an ownership interest in his excised biological materials was an issue of first impression to the California Supreme Court. Id. at 507 (Mosk, J., dissenting). As such, the absence of other court decisions granting a patient such an interest was irrelevant. Id. Second, property rights are sometimes described as sticks in a bundle of rights - with different sticks comprising different forms of property. Id. at 509. One such stick is the right to transfer. Id. Although California state law heavily regulated the disposition of excised human biological materials, the law granted patients the right to transfer such materials through donation, thereby implying that the patients had a limited property interest in such materials. Id. at $518 \mathrm{n} .23$. Lastly, the lack of informed consent remedy grants patients merely illusory protection of their biological materials. Id. at 519-20; see infra Part II.B. 
B. Greenberg v. Miami Children's Hospital Research Institute

In Greenberg, the parents of children afflicted with Canavan disease ${ }^{51}$ requested that a physician-researcher, Dr. Reuben Matalon, attempt to isolate the disease-causing gene. ${ }^{52}$ From this research, the parents anticipated the development and distribution of prenatal and carrier tests for Canavan disease on an affordable, accessible basis, as well as the discovery of more effective prevention techniques and, eventually, a cure for the disease. ${ }^{53}$ Consequently, they also expected Dr. Matalon's research would remain in the public domain. $^{54}$

To assist Dr. Matalon in his research, the parents, along with several nonprofit organizations, located other children afflicted with the disease to collect human biological materials. ${ }^{55}$ They then created a confidential database containing epidemiological, medical, and other information about the affected children and their families. ${ }^{56}$ With the funding, biological materials, and information provided by both the parents and non-profit organizations, Dr. Matalon successfully identified the Canavan disease gene. ${ }^{57}$ Shortly thereafter, without informing the parents or non-profit organizations, the Miami Children's Hospital patented the isolated genetic sequence. ${ }^{58}$ Under the patent, the hospital restricted access to all Canavan disease gene-related activity including "carrier and prenatal testing, gene therapy and other treatments . . . and research involving the gene and its mutations." hospital then created restrictive licensing agreements limiting the availability of Canavan disease testing and accessibility of the identified gene for research. ${ }^{60}$

51. Canavan disease is a rare but fatal genetic brain disorder most frequently afflicting Ashkenazi Jewish children. Canavan Foundation, What Is Canavan Disease?, http://www.canavanfoundation.org/ canavan.php (last visited Sept. 5, 2008). Symptoms include "rapidly increasing head circumference, lack of head control, reduced visual responsiveness and abnormal muscle tone such as stiffness or floppiness." Id. Afflicted children "cannot crawl, walk, sit or talk." Id. Moreover, "they may suffer seizures, become paralyzed, mentally retarded or blind and have trouble swallowing. ... Most children do not live past age 10." Id. The Canavan Foundation was a non-profit organization plaintiff in Greenberg. Greenberg v. Miami Children's Hosp. Research Inst., 264 F. Supp. 2d 1064, 1066 (S.D. Fla. 2003).

52. Greenberg, 264 F. Supp. 2d at 1066.

53. Id. at $1066-67$.

54. Id. at 1067.

55. Id. Such materials included blood, urine, and autopsy samples. Id.

56. Id.

57. $I d$.

58. Id. Dr. Matalon was an employee of the Miami Children's Hospital. Id.

59. Id.

60. Id. 


\section{Lack of Informed Consent}

The district court held that the parents and non-profit organizations failed to state a cause of action for lack of informed consent. ${ }^{61}$ While the court acknowledged that a medical researcher owes research volunteers a limited duty of informed consent, it refused to require a researcher to disclose economic interests for four reasons. First, such a requirement would give donors complete dominion over the purposes and beneficiaries of medical research. ${ }^{62}$ Second, such a requirement would be unworkable. ${ }^{63}$ Third, it would cause researchers to constantly evaluate whether a discloseable event occurred, thereby chilling medical research. ${ }^{64}$ Lastly, as the parents voluntarily donated their children's biological materials to medical research, they are not similarly situated to a patient whose biological materials are obtained for medical research on account of diagnosis and treatment. ${ }^{65}$ As such, the court determined that they should receive different treatment. ${ }^{66}$

\section{Conversion}

The district court next determined that the parents and non-profit organizations lacked a cause of action for conversion. ${ }^{67}$ Specifically, the plaintiffs did not retain an ownership interest in the children's excised biological materials because the materials were voluntarily donated without a contemporaneous expectation of return. ${ }^{68}$ In addition, the court found that

61. Id. at 1071 .

62. Id. at 1070 .

63. Id.

64. Id. at $1070-71$.

65. Id. at 1071 .

66. Id. The court's analysis contained certain weaknesses. First, although the court feared medical research would be chilled by requiring researchers to disclose economic interests, it ignored that Dr. Matalon and the hospital had already chilled medical research when they patented Dr. Matalon's research, thereby removing it from the public domain. Also, the court completely disregarded the American Medical Association's Code of Ethics, Professional Guidelines for Physician-Researchers, which required physician-researchers to disclose potential commercial applications to research volunteers and obtain their informed consent before realizing a profit on products developed from their biological materials. Id. at 1071 n.2 (citing Am. Med. Ass'n Council on Ethical and Judicial Affairs, Op. on Soc. Policy Issues E.208 (1990)).

67. Greenberg, 264 F. Supp. 2d at 1074.

68. Id. However, the parents and non-profit organizations did have certain expectations of return from their donation, such as public access to Dr. Matalon's research, affordable testing, more effective prevention techniques, and possibly a cure to Canavan disease. Id. at 1066-67. 
the conversion claim, which alleged the commercialization of Dr. Matalon's research exceeded the authorized use of the human biological materials, was too attenuated. ${ }^{69}$ Specifically, the court thought that such an expansive theory would cripple medical research by granting donors a continuing right to possess the results of any research conducted by the donee. ${ }^{70}$

\section{Washington University v. Catalona}

In Catalona, research participants donated biological materials ${ }^{71}$ to, and at the direction of, Dr. William Catalona, a researcher, urologist, and urologic surgeon at Washington University (WU). ${ }^{72}$ Prior to donation, the research participants completed an informed-consent form and signed a WU Genetic Research Brochure. ${ }^{73}$ Neither document indicated whether the research participants could have their materials sent to another research institution. ${ }^{74}$ However, the brochure did allow the participants to withdraw their materials and have them destroyed. ${ }^{75}$

The donated materials were stored in WU's Genito-Urinary (GU) Biorepository. ${ }^{76}$ Thus, if physician-researchers outside of WU desired access to the materials, they first had to complete a Material Transfer Agreement indicating that WU owned such materials. ${ }^{77}$ Additionally, WU's Intellectual Property Policy specified that WU owned all intellectual property, including tangible research property created with "significant [u]niversity resources" or "pursuant to a research project funded through corporate, federal, or other external sponsors administered by the [u]niversity." 78

Eventually, Dr. Catalona transferred from WU to a position at Northwestern University. ${ }^{79}$ Before his departure, however, he mailed his current and former research participants a letter requesting they release to him

\footnotetext{
69. Id. at $1075-76$.

70. Id. at 1076 .

71. Biological materials included prostate tissue, blood, and DNA samples. Wash. Univ. v. Catalona, 437 F. Supp. 2d 985, 988 (E.D. Mo. 2006), aff'd, 490 F.3d 667, 673 (8th Cir. 2007).

72. Id. Dr. Catalona specialized in prostate cancer research. Id.

73. Id. at 990 .

74. Id.

75. Id. Nevertheless, the research participants could not have the results obtained from their materials prior to withdrawal destroyed or recalled. $I d$.

76. Id. at 985 . The GU Biorepository housed human biological materials donated by WU physicians' research participants for prostate cancer research. Id. at $988 \&$ n. 3 .

77. Id. at 989

78. Id. (citation omitted)

79. Id. at 993 .
} 
any biological materials they contributed to the GU Biorepository. ${ }^{80}$ Approximately 6,000 research participants released their materials to Dr. Catalona. ${ }^{81}$

The district court determined that the research participants "parted with any semblance of ownership rights once their biological materials [were] ... excised for medical research" ${ }^{\prime 2}$ and that WU owned all biological materials in the GU Biorepository. ${ }^{83}$ Specifically, the court held that the research participants made an inter vivos gift of the subject biological materials to WU. ${ }^{84}$ The court defined an inter vivos gift as requiring: "(1) [the] present intention of the donor to make a gift; (2) delivery of property by donor to donee; and (3) acceptance by donee whose ownership takes effect immediately and absolutely." ${ }^{85}$

In concluding that the research participants had the present intention to make a gift, the court relied upon the informed consent forms that repeatedly asserted WU's ownership of the donated materials and did not advise the research participants that they entrusted their materials to Dr. Catalona. ${ }^{86}$

Nevertheless, Dr. Catalona and the research participants argued that the research participants' right to withdraw from a research protocol included the right to control "the use and location of their excised biological materials." 87 However, the court held that the right to withdraw only meant that the research participants had chosen to cease providing biological materials pursuant to a research protocol. ${ }^{88}$ The court based its holding upon two separate grounds. First, governing federal regulations did not provide the right asserted by Dr. Catalona and the research participants. ${ }^{89}$ Second, WU policy clearly indicated that once research participants discontinued their

80. Id. The letter included a "Medical Consent \& Authorization" form that Dr. Catalona directed the research participants to complete and return to him. Id. The form stated:

I have donated a tissue and/or blood sample for Dr. William J. Catalona's research studies.

Please release all of my samples to Dr. Catalona at Northwestern University upon his request.

I have entrusted these samples to Dr. Catalona to be used only at his direction and with his

express consent for research projects. Id.

81. Id.

82. Id. at 997.

83. Id. at 1002 .

84. Id. at 997.

85. Id.

86. Id. at $997,999$.

87. Id. at 999 .

88. Id. at 1000 .

89. Id. at 998 . 
participation in a research protocol, WU handled the participants' biological materials in one of three ways: destroying the materials, storing them indefinitely without further use, or removing all identifying markers and using the materials in exempt "anonymized" research..$^{90}$

Next, the court discussed certain policy implications concerning the argument of Dr. Catalona and the research participants. First, the court feared that granting the research participants ownership rights in the use and location of their biological materials would create a market for the materials such that the materials would become chattels selling for the highest price. ${ }^{91}$ Moreover, granting such rights would thwart medical research as such materials would be distributed to the highest bidder rather than the most important research protocol. ${ }^{92}$ Also, "[t]he integrity and utility of all biorepositories would be seriously threatened" because "individual samples would come and go" such that research protocols could no longer rely upon aggregate collections. ${ }^{93}$ Thus, "[these] institutions would [become mere] warehouses filling purchase orders." ${ }^{94}$ Finally, in granting such rights, prejudicial influences could enter medical research. ${ }^{95}$

\section{Policy Considerations}

Several important policies must be considered in determining whether research participants who donate biological materials for medical research should retain limited property rights in such materials. In making this determination, the interests of the research participants must be balanced

90. Id. at 999. Of note, Dr. Catalona and the research participants also argued that the research participants made a bailment of their biological materials to WU, designating WU as the bailee. $I d$. at 1001. However, the court rejected this argument, as it was inconsistent with the court's previous ruling that the research participants had made an inter vivos gift of the materials to WU. Id. Also significant were the facts that the research participants failed to inform WU that they wanted their materials returned when they "delivered" them to WU, federal and state regulations prohibited possession of such materials by the research participants, and the medical research community did not consider the relationship between a medical research institution and research participants to be a bailment. Id.

91. Id. at 1002 .

92. $I d$.

93. $I d$.

94. Id.

95. Id. Specifically, the court stated:

Allowing [research participants] to choose who can have the sample, where the sample will be stored, and/or how the sample can be used is tantamount to a blood donor being able to dictate that his/her blood can only be transfused into a person of a certain ethnic background, or a donated kidney being transplanted only into a woman or man. 
against society's interest in the free progression of medical research. ${ }^{96}$ Nevertheless, "considerations related to the well-being of the [research participants] should take precedence over the interests of science and society." 97 Research participants have three primary interests in favor of property rights in their biological material: (1) dignity, (2) autonomy, and (3) economic profitability. Each interest implicates important concerns for which any ownership regime must adequately account.

\section{A. Research Participants' Interest in Dignity}

A research participant's interest in dignity is comprised of three important notions. First, an unequal amount of information exists between research participants and physician-researchers. ${ }^{98}$ Specifically, while physicianresearchers may know that a research participant's biological materials are extremely valuable, the research participant himself may be totally unaware of this possibility. ${ }^{99}$ Moreover, because research participants generally do not seek legal relief after their biological materials have been used for profit, a coherent and predictable policy governing the collection, distribution, and use of such materials does not exist. ${ }^{100}$ As such, to restore research participants' dignity, the disparity of information between themselves and physicianresearchers must be equalized. ${ }^{101}$ Thus, research participants should know "the nature of the intended research, what the research hopes to accomplish and who will benefit medically and monetarily." 102

The second component of a research participant's dignity interest is the sanctity of the human body. ${ }^{103}$ Theoretically, "nothing is more one's own than one's body." 104 Conceivably, the belief that research participants should have unlimited ownership rights in their biological materials logically flows. However, unlimited rights may instead demean the sanctity of the human body

96. Prowda, supra note 16 , at 638-39.

97. Declaration of Helsinki, supra note 16, $\uparrow$ A-5.

98. Charlotte H. Harrison, Neither Moore nor the Market: Alternative Models for Compensating Contributors of Human Tissue, 28 AM. J.L. \& MED. 77, 82 (2002).

99. Id.; see also Moore v. Regents of the Univ. of Cal., 793 P.2d 479, 485-86 (Cal. 1990).

100. Harrison, supra note 98 , at 83.

101. Prowda, supra note 16 , at 636.

102. Id. (footnote omitted).

103. Boulier, supra note 6 , at 716 .

104. Id. (footnote omitted). 
because of special considerations associated with it and its constituent parts. ${ }^{105}$ Specifically, as one commentator explained:

[Property law] treat[s] goods considered "property" primarily as market goods. . . . $[\mathrm{M}]$ arket goods are optimally distributed through the auspices of the market which takes into account all the values and disvalues pertaining to a good and allocates the good in such a manner as to maximize overall value. The human body and its component parts are not, however, market goods. This is so because many modes of valuing the body cannot be translated into or understood in terms of a market price. $^{106}$

Nevertheless, consistent with the progression of technology, society has allowed "the body to be used in various ways that would have once been unacceptable under an older conception of the body."107 For example, commercial interests in the human body are rapidly growing. ${ }^{108}$ In the wake of such societal changes, limited ownership rights in human biological materials may protect the dignity of the human body because such rights would grant research participants an "enforceable stake" in their biological materials, allowing them to control such materials even upon removal. ${ }^{109}$

The final notion included in a research participant's dignity interest is altruism. Among other motivations, research participants donate their biological materials as a public charity. ${ }^{110}$ To effectuate the participants' donative intent, research institutions and physician-researchers must be limited to prevent them from exploiting research-participant altruism. Such boundaries may be set by allowing research participants a limited ownership right in their biological materials.

\section{B. Research Participants' Interest in Autonomy}

A research participant also has a significant interest in autonomy. Both judicial decisions and legislation establish that individuals have the right to make decisions regarding their bodies. ${ }^{111}$ In the context of human biological

105. Id. at 717 .

106. Gold, supra note 6, at 1171 (footnote omitted).

107. Boulier, supra note 6 , at 718 .

108. Id. at 719 .

109. $I d$.

110. Thomas P. Dillon, Note, Source Compensation for Tissues and Cells Used in Biotechnical Research: Why a Source Shouldn't Share in the Profits, 64 Notre Dame L. Rev. 628, 638-39 (1989).

111. Hannah Horsley, Reconsidering Inalienability for Commercially Valuable Biological Materials, 29 HARV. J. on Legis. 223, 237 (1992). For example, informed consent laws, privacy rights, and research subject protection laws. $I d$. 
materials, however, informed consent laws are the most relevant. Unfortunately, such laws do not adequately protect research participants' autonomy interests.

Specifically, in Moore, Justice Mosk explained how informed-consent laws grant research participants only illusory protection of their biological materials. ${ }^{112}$ Specifically, patients claiming a lack of informed consent must prove that: (1) had they been informed of the undisclosed information they would not have consented to the procedure in question; and, (2) in the same situation a reasonably prudent person would not have consented either. ${ }^{113}$ However, in cases like Moore, the potential treatment benefit - a life-saving operation-generally outweighs the undisclosed risk of the physician using the biological materials for research or commercial product development. ${ }^{114}$ Therefore, a trier of fact will most likely conclude that a reasonably prudent person would have consented to the procedure in question. ${ }^{15}$

Moreover, Greenberg determined that a physician-researcher owes no continuing duty of informed consent to research volunteers who lack a "clinical relationship" with the physician-researcher. ${ }^{116}$ Thus, a physicianresearcher need not "disclose any information that might influence [the research participants'] decision to participate or decline to participate" in the research. ${ }^{117}$

In both situations informed consent laws did not protect research participants' autonomy interest. Instead, the participants were stripped of their right to make decisions regarding their own bodies. In light of these offensive outcomes, if research participants are not granted limited property rights in their biological materials, they may refuse to donate such materials, thereby chilling medical research. ${ }^{118}$ Without such rights, participant autonomy is undermined and physician-researchers, research institutions, and biotechnology companies gain "unchecked authority to involve [participants] in research and development." 119

112. Moore v. Regents of the Univ. of Cal., 793 P.2d 479, 519-20 (Cal. 1990) (Mosk, J., dissenting).

113. Cobbs v. Grant, 502 P.2d 1, 11-12 (Cal. 1972).

114. Moore, 793 P.2d at 520.

115. Id.

116. See Greenberg v. Miami Children's Hosp. Research Inst., Inc., 264 F. Supp. 2d 1064, 1068 (S.D. Fla. 2003).

117. $I d$.

118. Prowda, supra note 16 , at 632.

119. Id. (footnote omitted). 


\section{Research Participants' Economic Interest}

Lastly, research participants have an economic interest in their biological materials. As previously mentioned, research participants provide the raw materials of medical research without compensation. In return for their contribution, they typically expect broad access to affordable products such as medication, therapy, and testing. ${ }^{120}$ However, such expectations are generally not realized.

Granting research participants limited property rights in their biological materials may promote a redistribution of wealth among research participants, physician-researchers, research institutions, and biotechnology companies. Currently, the number of patents in the biotechnology industry is everincreasing and "secrecy is fast becoming the norm." 121 Additionally, patents and secrecy also serve to increase end-user health care costs. Granting research participants limited property rights would allow them greater control over the distribution of their biological materials and permit them to choose physician-researchers less likely to commercialize the fruits of their medical research.

\section{ReCOMmendation}

"[P]roperty [law $]$ is an abstraction. It refers not to things, ... but to rights or relationships among people with respect to things." 122 Thus, in its purest form, property law assigns individuals legal rights to things of value in our society. For many years, however, the human body and its constituent parts were considered "worthless." ${ }^{123}$ As such, the only property rights that existed were related to the disposition of corpses. ${ }^{124}$ However, as biotechnology evolved, the value of the human body similarly appreciated. ${ }^{125}$ In particular, human biological materials became extremely important to medical research. ${ }^{126}$ Now, these once useless materials constitute the raw materials used to create "life saving medicines and therapies" and have become a "billion dollar industry." 27

120. See, e.g., Greenberg, 264 F. Supp. 2d at 1067.

121. Boulier, supra note 6, at 725 (footnote omitted).

122. Jesse Dukeminier \& James E. Krier, Property 93 (5th ed. 2002).

123. Dillon, supra note 110 , at 630 .

124. $I d$.

125. Id. at 630-31.

126. $I d$.

127. Boulier, supra note 6, at 694 . For example, in 1987 the federal government spent upwards of 
The concept of "[property] consists of a number of disparate rights, a 'bundle' of them: the right to possess, the right to use, the right to exclude, [and] the right to transfer." 128 However, all forms of property do not possess the same bundle of rights. ${ }^{129}$ Instead, the law "limits or even forbids the exercise of certain rights over certain forms of property." 130 Thus, while such limitations or prohibitions may "diminish[] the bundle of rights that would otherwise attach to the property, ... what remains is still deemed in law to be a protectible property interest." 131 Furthermore, although society attaches different values to each disparate property right, "[rights] traditionally associated with personal liberties such as [privacy (the right to exclude) and freedom of choice and movement (the right to transfer)] receive[] greater protection from governmental encroachment." 132

All persons possess certain constitutional rights "which can never be suppressed without challenging the person's very dignity and existence."133 These rights include "the right to due process, the right to own property, the right to bodily integrity, the right to live, and the right not to be owned." 134 Accordingly, all persons possess a constitutional right in their own bodies. ${ }^{135}$ As the courts in Moore, Greenburg, and Catalona held, however, their rights with respect to donated biological materials may be more limited. ${ }^{136}$ In particular, they generally do not retain any property interest in such materials. ${ }^{137}$ Research participants who donate human biological materials for

\$2 billion dollars on biotechnology research and development. Id. at 694 n.6 (citing U.S. Congress, Office of Tech. Assessment, New Developments in Biotechnology: U.S. Investment in Biotechnology 3 (1988)); see also Moore v. Regents of the Univ. of Cal., 793 P.2d 479, 482 (Cal. 1990) (stating lymphokines derived from Moore's spleen were potentially part of a $\$ 3$ billion-dollar market in the biotechnology industry).

128. Dukeminier \& KrIER, supra note 122, at 93. These disparate rights are often referred to as "sticks" in a "bundle" of property rights. Dillon, supra note 110, at 632.

129. Moore, 793 P.2d at 509 (Mosk, J., dissenting).

130. Id. For example, while "[a] sportsman may give away wild fish or game that he has caught or killed pursuant to his license, he may not sell it." Id. at $510 \mathrm{n} .10$ (citation omitted).

131. Id. at 510 .

132. Dillon, supra note 110, at 632-33 (citing P. Salsich, Parcelization-Can Segments of Property be 'Taken'? Does the Court Mean What It Said in Keystone? 17 (Aug. 9, 1988) (unpublished manuscript)).

133. Philippe Ducor, The Legal Status of Human Materials, 44 Drake L. Rev. 195, 199 (1996); see also U.S. Const. amend. XIII, § 1; U.S. Const. amend. XIV, § 1.

134. Ducor, supra note 133, at 199 (footnotes omitted).

135. Id. The author refers to the presence of all of these rights as the "hard nucleus" of constitutional rights. Id. Entities with rights that fall short of this "hard nucleus" are considered objects, not persons. Id.

136. See supra Part I.

137. See id. 
medical research should, however, retain limited rights to exclude and transfer with respect to their materials. ${ }^{138}$

\section{A. The Fee Simple Defeasible}

To accomplish this objective, the legislature could grant research participants the right to create a fee simple defeasible in their excised biological materials and mandate health care providers to inform participants of this right as part of informed consent. Currently, fee simple defeasibles are used in conjunction with real property donations. ${ }^{139}$ A fee simple defeasible ownership interest may endure forever or may cease upon the occurrence of a future event. ${ }^{140}$ In addition, two types of fee simple defeasibles exist: the "fee simple determinable" and the "fee simple subject to a condition subsequent." context of human biological materials.

A fee simple determinable ownership interest is extremely limited. ${ }^{142}$ Specifically, the interest automatically expires when a stated event transpires. ${ }^{143}$ Also, to create such an interest the donor must use specific language indicating the durational aspect of the interest; language merely stating the donor's motive for making the gift is not enough. ${ }^{144}$

Through a fee simple determinable, research participants could donate their biological materials to a research institution so long as a certain physician-researcher receives them. This protects research participants' interests in privacy and autonomy. For example, if a research participant's trusted physician removes a cancerous tumor from the participant, the participant could designate the tumor to be used only in that particular physician's research. In addition, this approach encourages the free exchange of information. For example, a research participant could specifically designate a physician-researcher that the participant believes will leave any information discovered in the public domain. Additionally, once the

138. See id.

139. See Dukeminier \& KrIER, supra note 122, at 240.

140. Id.

141. Id. at 240-41.

142. Id. 240.

143. Id.

144. Id. at 241. For example, $A$ creates a fee simple defeasible if $A$ conveys Blackacre to the City "so long as the land is used as a public park." Id. However, $A$ creates a fee simple absolute if $A$ conveys Blackacre to the City "for the purpose of a public park." Id. A fee simple absolute cannot be divested and will not end upon the occurrence of a stated event. Id. at 240. 
physician-researcher receives such materials, the research participant could no longer control its use or transfer. This ensures the unhindered progression of medical research by limiting the control research participants have over their biological materials.

\section{B. Creation of the Fee Simple Determinable}

Although property law is derived from the common law, "the [1] egislature ... is [clearly] the proper deliberative forum" to grant research participants the power to create a fee simple defeasible in their biological materials. ${ }^{145}$ Current state and federal laws view such materials as sui generis, "regulating their disposition to achieve policy goals rather than abandoning them to the general law of personal property." 146 Accordingly, the legislature has the proper resources to determine whether to extend the fee simple defeasible to human biological materials.

More specifically, because this issue requires a uniform solution, Congress is the appropriate legislature to grant research participants such rights. Although the states generally regulate both property law and the disposal of human biological materials, Congress has enacted comprehensive legislation regarding such materials, thereby demonstrating its competency in the area. ${ }^{147}$ Unfortunately, Congress also has demonstrated susceptibility to powerful interest groups. For example, former Vice President Al Gore described the Medicare prescription drug benefit as "a token plan designed to trick the voters and satisfy pharmaceutical companies."148 Specifically, Congress restricted the federal government from negotiating Medicare drug prices even though the government already negotiates drug prices for both Medicaid and the Veteran's Administration. ${ }^{149}$ This created higher drug costs

145. Moore v. Regents of the Univ. of Cal., 793 P.2d 479, 498 (Cal. 1990) (Arabian, J., concurring).

146. Id. at 489 (majority opinion); see also CAL. Health \& SAFETy Code $§ 7054.4$ (West 2007) (" $[\mathrm{H}]$ uman tissues ... following conclusion of scientific use shall be disposed of by interment, incineration, or any other method determined by the state department [of health services] to protect the public health and safety.”); Unif. ANAtomical Gift Act § 11, 8A U.L.A. 53 (amended 2006) (establishing that only hospitals, physicians, surgeons, procurement organizations, accredited medical or dental schools, and designated individuals can receive anatomical gifts for certain enumerated purposes).

147. See National Organ Transplant Act, 42 U.S.C. $\S \S 273-274 g$ (2000).

148. Al Gore, Editorial, Broken Promises and Political Deception, N.Y. Times, Aug. 4, 2002, $\S 4$, at 13 , available at 2002 WLNR 4022031.

149. Richard G. Frank, Prescription Drug Prices, 351 New ENG. J. Med. 1375, 1376 (2004). 
for Medicare beneficiaries and greater profits for pharmaceutical companies. ${ }^{150}$

With respect to human biological materials, both biotechnology and pharmaceutical companies are entrepreneurial profit-seeking entities. Because they use such materials in extremely expensive, high risk research projects, they traditionally desire unconditional title to the materials. As a result, they will most likely oppose granting research participants the right to create a fee simple defeasible and its associated conditions in such materials. Consequently, they may exert political pressure on Congress to impede the passage of legislation expanding the rights of research participants in their biological materials.

\section{Enforcement of the Fee Simple Determinable}

A fee simple determinable ownership interest is accompanied by a future interest - either a possibility of reverter or an executory interest. ${ }^{151}$ While a possibility of reverter is retained by the donor, an executory interest is created in another donee. ${ }^{152}$ In addition, if the fee simple determinable interest holder violates its stated condition, the interest passes to the future interest holder by operation of law. ${ }^{153}$

As state laws prohibit persons from possessing their excised biological materials, a possibility of reverter could not be used in conjunction with such materials. ${ }^{154}$ However, an executory interest could designate a contingent physician-researcher recipient should the primary recipient fail to receive the donated biological materials. In addition, if the research institution does not distribute the materials in accordance with the fee simple determinable condition, the research participant could have an equitable cause of action for injunctive relief ordering that the materials either be placed with the designated physician-researcher or destroyed. A downside to judicial intervention, however, is that the process is both slow and can be very costly.

150. David Espo, Veto Threat Hangs Over Medicare Bill, Pittsburgh Post-Gazette, Jan. 12, 2007, at A5, available at 2007 WLNR 663888.

151. Dukeminier \& KRIER, supra note 122 , at $241 \&$ n. 27.

152. $I d$.

153. Id. at 241 .

154. See, e.g., ARK. Code AnN. § 20-17-801 (West 2007) (mandating that human tissue must be disposed of in a sanitary method, approved of by the state board of health); CAL. HEALTH \& SAFETY CODE $\S 7054.4$ (West 2007); OKLA. AdMIN. CODE $§ 435: 10-7-9$ (2007) (providing that human tissue must be handled in one of four enumerated ways). 
This may have a detrimental effect on donated material with a limited useful life.

\section{CONCLUSION}

A commentator once noted that although "the law marches with medicine," it does so "in the rear and limping a little." 155 Indeed, as new uses for the human body and its component parts have evolved, so too has the body's value appreciated. Laws governing the body's disposition, however, have not kept pace with this trend. In particular, laws dictating research participants' rights with respect to their biological materials have failed to adequately protect important participant interests, including dignity, autonomy, and economic concerns.

As illustrated through Moore, Greenberg, and Catalona, research participants do not retain an ownership interest in their excised biological materials. However, research participants may nevertheless be able to donate such materials pursuant to the laws of certain states. Unfortunately, under the current legal framework, participants' altruistic donations are likely to be abused. For example, physician-researchers may fail to disclose either the value of a participant's biological materials or patent information to create higher end-user product costs. Undoubtedly, research participants need greater control over their biological materials to prevent such abuse-control which should properly flow from Congress.

Specifically, research participants who donate biological materials for medical research should retain limited rights to exclude and transfer with respect to their materials. This can be achieved by granting participants the right to create a fee simple determinable in such materials. A fee simple determinable will appropriately balance significant policy considerations to ensure the free progression of medical research is consonant with the protection of important research-participant interests. The current absence of donor rights demands that action be taken to prevent future abuse.

155. Boulier, supra note 6, at 695 (citing Sir Zelman Cowen, Reflections on Medicine, BioteCHNOLOGY AND THE LAW 5 (1986)). 